In cases $1-4$ it was difficult to measure the visual function due to the patients' mental retardation and/or behavioural disturbance. Case 6 gives an indication of the degree of unaided visual improvement that can be expected in epikeratoplasty for keratoconus. ${ }^{5}$ Where there is significant corneal scarring deep lamellar keratoplasty with lyophilised tissue can be used, ${ }^{6}$ and this latter technique could perhaps also benefit from botulinum toxin induced ptosis as part of the early postoperative management.

In conclusion, our case reports suggest that therapeutic botulinum toxin ptosis is a useful adjunct in the management of patients undergoing epikeratoplasty with freeze dried tissue since it promotes stabilisation of the epithelium on the graft.
Mr Tim Freegard is a research registrar funded by The Guide Dogs for the Blind Association. This paper was presented at the VIth European Refractive Surgery Society Meeting, Siena, 1-3 October 1992, and at the UK Intra-ocular Implant Society Meeting, Birmingham, October 1992.

1 Frantz JM, Gebhardt BM, Reidy JJ, McDonald MB. Immunogenicity of epikeratophakia tissue lenses containing living donor keratocytes. Refract Corneal Surg 1991; 7: living don.

2 Steinert RF, Grene RB. Postoperative management of epikeratoplasty. F Cataract Refract Surg 1988; 14: 255-64.

3 Kirkness CM, Adams GGW, Dilly PN, Lee JP. Botulinum toxin A-induced protective ptosis in corneal disease. Ophthalmology 1988; 95: 473-80.

4 Rostron CK, Sandford-Smith JH, Morton DB. Experimental epikeratophakia using tissue lathed at room temperature. Br f Ophthalmol 1988; 72: 354-60.

5 Uusitalo RJ, Lehtosalo J, Klyce SD. One-year follow-up of epikeratophakia for keratoconus. Graefes Arch Clin Exp Ophthalmol 1989; 227: 401-7.

6 Chau GK, Dilly SA, Sheard CE, Rostron CK. Deep lamellar keratoplasty on air with lyophilised tissue. $\mathrm{Br} \mathcal{J}$ Ophthalmol 1992; 76: 646-50.

\title{
Exotropia as a sign of myasthenia gravis in dysthyroid ophthalmopathy
}

\author{
Marino E Vargas, Floyd A Warren, Mark J Kupersmith
}

\section{New York University Medical Center, New York Eye and Ear Infirmary \\ Department of Ophthalmology ME Vargas F A Warren M J Kupersmith}

Department of Neurology M J Kupersmith Correspondence to: Mark J Kupersmith, MD 530 First Ave 3B, New York, NY 10016, USA.

Accepted for publication 13 July 1993

\begin{abstract}
The association between thyroid disorders and myasthenia gravis (MG) has long been recognised. The occurrence of Graves' disease is reported in $3-10 \%$ of myasthenic patients. ${ }^{1}$ In contrast, $M G$ occurs in considerably less than $1 \%$ of dysthyroid patients. ${ }^{2}$ When a full blown thyroid ophthalmopathy, systemic myopathy, or both are present, additional muscle weakness caused by the onset of MG may be difficult to detect by examination alone. We present four patients with dysthyroid orbital disease who developed exotropia and variable ptosis caused by MG. Subsequent review of the records of 91 patients with dysthyroid orbitopathy, none of whom had MG when evaluated, revealed no additional cases with exotropia.
\end{abstract}

\section{Case reports (Tables 1, 2)}

Four patients with typical signs of dysthyroid orbitopathy had the new onset of diplopia. All

Table 1 Ocular motility evaluation

\begin{tabular}{llllll}
\hline Case & Age/sex & $\begin{array}{l}\text { Ptosis } \\
(R / L)\end{array}$ & $\begin{array}{l}\text { Proptosis } \\
(m m R / L)\end{array}$ & $\begin{array}{l}\text { Edrophonium } \\
\text { response }\end{array}$ & $\begin{array}{l}\text { Ocular deviation } \\
\text { Primary gaze }(D)\end{array}$ \\
\hline 1 & $60 / \mathrm{F}$ & Mild R & $3 \mathrm{~L}$ & $\begin{array}{l}\text { Infraduction R/L } \\
\text { Ptosis }\end{array}$ & XT 45, LHT 2 \\
2 & 60/F & $\begin{array}{l}\text { Moderate L } \\
\text { Mild R }\end{array}$ & $5 \mathrm{R} / \mathrm{L}$ & $\begin{array}{l}\text { Not performed } \\
\text { Infraduction R/L } \\
\text { Horizontal gaze R/L } \\
\text { Ptosis } \\
\text { Horizontal gaze R/L } \\
\text { Ptosis }\end{array}$ & XT 30, RHT 20 \\
4 & 48/M & Mild R/L & $4 \mathrm{R} / \mathrm{L}$ & XT 40 \\
\hline
\end{tabular}

four patients were being treated with methimazole (Tapazole) or propylthiouracil or had been treated for hyperthyroidism. In each patient, the examination of the visual sensory system, pupils, anterior segment, intraocular pressure, and fundus was normal. Varying degrees of ocular motility limitation resulted from both the thyroid disease and MG. In primary gaze, an exotropia from 5 to 45 dioptres was measured in all four patients. Ptosis associated with proptosis and lid oedema in addition to MG occurred in all four patients. An edrophonium test was positive in three patients; the test was deferred in the fourth because of unstable arrhythmias. The serum acetylcholine receptor antibody assay was negative in all four patients. Three patients had marked improvement after treatment with oral prednisone, started at $60 \mathrm{mg} / \mathrm{kg}$ per day and tapered over $4-6$ weeks. The fourth patient had a positive skin test for tuberculosis which precluded corticosteroid therapy. Computed tomography (CT) of the orbits, performed in two patients, showed bilateral enlargement of inferior and medial rectus. CT of the chest in all four patients showed no thymoma.

\section{Comment}

Clinical differentiation between MG and dysthyroid orbitopathy is usually not difficult. Although the extraocular muscles are frequently 
Table 2 Ocular motility change with prednisone therapy

\begin{tabular}{|c|c|c|c|}
\hline Case & Ocular motility limitation & Forced duction & $\begin{array}{l}\text { Prednisone induced } \\
\text { improvement }\end{array}$ \\
\hline 1 & $\begin{array}{l}\text { Supraduction } R / L \\
\text { Infraduction } R / L \\
\text { Abduction R/L M } \\
\text { Adduction R/L S }\end{array}$ & $\begin{array}{l}\text { Supraduction } \mathrm{R} / \mathrm{L}+ \\
\text { Adduction } \mathrm{R} / \mathrm{L}-\end{array}$ & $\begin{array}{l}\text { Horizontal gaze } \mathrm{R} / \mathrm{L} \\
\text { Ptosis }\end{array}$ \\
\hline 2 & Interior rectus $S$ & $\begin{array}{l}\text { Infraduction } \mathrm{R}- \\
\text { Adduction } \mathrm{R}- \\
\text { Supraduction } \mathrm{R} / \mathrm{L}-\end{array}$ & $\begin{array}{l}\text { Inferior rectus } \\
\text { Ptosis }\end{array}$ \\
\hline 3 & $\begin{array}{l}\text { Adduction R/L S } \\
\text { Abduction R/L M } \\
\text { Infraduction L S }\end{array}$ & & $\begin{array}{l}\text { Adduction } \mathrm{R} / \mathrm{L} \\
\text { Abduction } \mathrm{R} / \mathrm{L} \\
\text { Infraduction } \\
\text { Ptosis }\end{array}$ \\
\hline 4 & $\begin{array}{l}\text { Supraduction R/L S } \\
\text { Infraduction R/L S } \\
\text { Adduction R/L S } \\
\text { Abduction R/L S }\end{array}$ & $\begin{array}{l}\text { Supraduction R/L + } \\
\text { Abduction } R / L ~-~\end{array}$ & Not treated \\
\hline
\end{tabular}

$\mathrm{R}=$ right eye; $\mathrm{L}=$ left eye; $M=$ mild; $S=$ severe.

involved in both disorders, in Graves' disease a restrictive myopathy, usually of the inferior and medial recti, occurs. Diplopia and deficits of supraduction and abduction causing esotropia and hypotropia are common, but exotropia is rare. ${ }^{3-6}$ This is supported by a review of our records of patients with dysthyroid orbital disease alone which did not reveal a case with exotropia.

In ocular MG, variable ptosis and ophthalmoparesis occur. ${ }^{78}$ Diplopia or ptosis is present at the onset of MG in up to $70 \%$ of patients.' During the course of $M G$, ocular symptoms will develop in $90 \%$ of patients. ${ }^{79}$ Orbicularis oculi weakness is also common with ocular myasthenia. Although not seen in our patients, a lid twitch can be elicited in $50 \%$ of myasthenic patients. ${ }^{79}$ Myasthenia gravis does not have a predilection for a particular extraocular muscle. The initial ocular manifestation typically involves more than one extraocular muscle without a consistent pattern of dysfunction. ${ }^{710} \mathrm{How}-$ ever, when a solitary paresis occurs it commonly results in an adduction deficit." Weakness of the voluntary muscles of the head and neck is common in MG and rare in thyroid disease. ${ }^{10}$

In addition to the obvious differences, both diseases share some features, principally weakness and fatiguability of voluntary muscles. ${ }^{4}$ The course of either disorder can be marked by spontaneous crises and remissions or chronic progression of muscle dysfunction. A cursory clinical examination can lead to an incomplete diagnosis. Lid retraction, a dysthyroid sign, may be apparent in $M G$ in the lid contralateral to a ptotic lid. ${ }^{12-14}$ Upper lid ptosis, typically mild and usually very suggestive $M G$, can be seen with Graves' disease because of oedema, infiltration, and levator myopathy. ${ }^{15}$ Among those with both disorders, hyperthyroidism appears first in 54\%, MG first in 37\%, and both occur simultaneously in $9 \%$ of patients. ${ }^{3}$

These two entities can also be distinguished by pharmacological responses. Thyroid myopathy is not reversed by edrophonium or pyridostigmine and treatment with corticosteroids is of minimal benefit. In contrast, ocular MG typically normalises with small doses of edrophonium and improves with a short course of moderate dose corticosteroids. ${ }^{16}$ In our four patients the presence of both a variable ptosis and exotropia suggested concomitant MG. The marked responsiveness to corticosteroids and edrophonium further indicated that the ocular motility disturbance was not solely due to a restrictive myopathy.

Supported by Research to Prevent Blindness, Inc and the RL Kohns Foundation.

1 Kiessling WR, Fink ER, Kotulla P, Schleusener H. Circulating TSH - binding inhibiting immunoglobulins in myasthenia gravis. Acta Endocrinol 1982; 101: 41-6.

2 Drachman B. Myasthenia gravis and the thyroid gland. N Engl F Med 1962; 266: 330-3.

3 Milliken $\mathrm{CH}$, Haines SF. Thyroid gland in relation to neuromuscular disease. Arch Intern Med 1953; 92: 5-39.

4 Engel AG. Neuromuscular manifestations of Graves' disease. Mayo Clin Proc 1972; 47: 919-25.

5 Caygill WM. Excyclotropia in dysthyroid ophthalmopathy. Am f Ophthalmol 1972; 73: 437-41.

6 Wiersinga VM, Smit T, vander Gaag R, Mourits M, Kourneef L. Clinical presentation of Graves' ophthalmopathy. Ophthalmic Res 1989; 21: 73-82.

7 Schlezinger NS, Fairfax WA. Evaluation of ocular signs and symptoms in myasthenia gravis. Arch Ophthalmol 1959; 62: 985-90.

8 Spoor TC, Shippman S. Myasthenic gravis presenting as an isolated inferior rectus paresis. Ophthalmology 1979; 86 2158-60.

9 Cleary PE. Ocular manifestations of myasthenia gravis. $\mathrm{Br}$ Orihopt f 1973; 30: 38-51.

10 Acers TE. Ocular myasthenia gravis mimicking pseudointernuclear ophthalmoplegia and variable esotropia. Am $\mathcal{J}$ Ophthalmol 1979; 88: 319-21.

11 Cogan DE. Myasthenia gravis. Arch Ophthalmol 1965; 74: 217-21.

12 Hatch HA. Myasthenia gravis: report of a case with exophthalmos without hyperthyroidism, relieved by neostigmine. NEnglf Med 1952; 246: 856-8.

13 Weickhardt GB, Redmond AJ. Myasthenia gravis and hyperthyroidism: report of two cases and review of the literature. Ann Intern Med 1960; 52: 1246-56.

14 Kansu T, Subutay N. Lid retraction in myasthenia gravis. f Clin Neuro-ophthalmol 1987; 7: 145-8.

15 Burde RM. Graves' ophthalmopathy and the special problem of concomitant ocular myasthenia gravis. Am Orthopt $\mathcal{F}$. 1990; 40: 37-50

16 Kupersmith $M$, Weinberg H, Frohman L, Warren F, Breinin G. Ocular myasthenia: diagnosis and treatment. In: Smith JL, Katz RS, eds. Neuro-ophthalmology enters the nineties. Hialeah, FL; Dutton Press, 1988: 173-82. 